Kia et al./Sokoto Journal of Veterinary Sciences, 16(2): 75 - 82.

\title{
Occurrence of Salmonella and Shigella in edible frogs (Hoplobatrachus spp) from Hanwa Frog market Zaria, Nigeria
}

\author{
GSN Kia*, EA Benjamin, EO Ajani \& GR Otolorin \\ Department of Veterinary Public Health and Preventive Medicine, Faculty of Veterinary Medicine, Ahmadu Bello University \\ Zaria, Nigeria
}

*Correspondence: Tel.: +2348036148870; E-mail: gracegracekia@yahoo.com

Copyright: (c) 2018 Kia

et al. This is an open-

access article published

under the terms of the

Creative Commons

Attribution License

which permits

unrestricted use,

distribution, and reproduction in any medium, provided the original author and source are credited.

Publication History:

Received: 04-10-2017

Accepted: 22-02-2018

\section{Abstract}

Frogs have been associated with bacterial infection among those who handle them resulting in symptoms such as diarrhoea, abdominal cramps, fever and vomiting. Frogs are a rich source of proteins and they are considered a delicacy by some in Nigeria. Considering the high demand for edible frogs, it is important to determine the occurrence of Salmonella and Shigella organisms from edible frogs (Hoplobatrachus spp). Edible frogs ( $n=202$ ) were collected from February to July, 2016, from the Hanwa frog market, Zaria, Kaduna State. The intestinal contents of each sampled frog were scraped into the selenite broth bottles and cultured on Deoxycholate Citrate Agar for enrichment and isolation respectively. Biochemical test and sugar fermentation tests were carried out on the suspected isolates. Overall, twenty seven $27(13.37 \%)$ of the processed samples were suggestive of Shigella, while 22(10.9\%) were suspect Salmonella organisms. There was no significant association between sex of the frogs and the isolation of Shigella and Salmonella organisms, despite the high occurrence of Shigella organism (14.17\%) in the males. Source wise the occurrence of Salmonella in frogs was high in Tudun Wada (20\%), while Katsina (8.5\%) had the least. There was also no association between source and Shigella organisms. Frogs within the weight range of 175-224g had the highest occurrence rate for Shigella isolation, while frogs of 73$125 \mathrm{~g}$ weight range had the highest occurrence rate for Salmonella isolation. This study shows the presence of Shigella and Salmonella organisms in the intestinal contents of frogs. Therefore the unhygienic and unsanitary environment, handling and processing of frogs is of great public health concern and as such measures are to be put together to ensure safety and wholesomeness of the frog meat been sold for human consumption.

Keywords: Edible, Frog, Safety, Salmonella, Shigella, Zaria

\section{Introduction}

Frogs belong to a diverse and largely carnivorous group of short bodied tailless amphibians composing the order Anura (Singh, 2017). Frogs can come into direct contact with various bacteria constantly, which may be present in the soil, water body or present in the arthropods that they eat (Rebollar et al., 2016). Frogs may be predisposed to bacterial infection when they are stressed. Pathogens build up in enclosed environments where frogs can be found and can cause infection (PetMD, 2008). The bacterial organisms commonly affecting frogs predilect in their gastrointestinal tract, thus upon consumption by man would result in infection by the presence of bacteria toxin (Marler, 2009). 
Salmonella is a rod shaped gram negative bacteria of the family Enterobacteriaceae. Salmonella species are facultative intracellular pathogens, many infections are due to the ingestion of contaminated food (Ryan \& Ray, 2004). Frogs have been reported to serve as reservoir host of Salmonella organisms; pathogenic strains of Salmonella may be transmitted from frogs to human by the faecal-oral route (Hoelzer et al., 2011). Salmonella anatum, Salmonella poona and Salmonella richmond from frogs seem important in the epidemiology of Salmonella infections because of the association between these serotypes with man and domestic animals (Leeuwenhoek et al., 1974).

The actual number of the human population in Nigeria has doubled during the past 20 years and is need for animal protein consumption has also increased, thereby resulting in increased, consumption of frogs; therefore, the greater the number of the populace consuming it, the greater the infectivity rate in cases of unhygienic preparation methods (CDC, 2008).

Shigella is a genus of Gram-negative, facultative anaerobic, non-spore-forming, non-motile, rodshaped bacteria closely related to Salmonella . The genus is named after Kiyoshi Shiga, who first discovered it in 1897 (Yabuuchi, 2002). Aquatic bodies have been reported to be contaminated with human faeces and this can expose the water bodies to Shigella organisms. This may result in infection of frogs leading to decline in their population. When frog meat is undercooked, it may result in zoonotic disease in humans. Human cases of Shigella are typically acquired through contact with infected persons or ingestion of food contaminated with Shigella bacteria (Gupta et al., 2004).

The consumption of frog in many part of the world and in Nigeria in particular, is on the increase. (Stuart et al., 2004). In Nigeria, frogs are collected on a local scale for human consumption as an essential source of animal protein. There is little or no work done on the isolation of Shigella spp and Salmonella spp from intestinal contents of edible frogs in Zaria Kaduna State, Nigeria. Hence, the need for this research.

\section{Materials and Methods}

\section{Study area}

The study area is Hanwa frog market, located in Zaria Local Government Area of Kaduna State. It is about $141 \mathrm{mi}$ (or $227 \mathrm{~km}$ ) North of Abuja, Nigeria`s Federal capital city. The area located at latitude $11^{\circ} 04^{\prime} \mathrm{N}$ and longitude $7^{\circ} 42^{\prime} \mathrm{E}$. Edible frogs (Hoplobatrachus spp) used for this study were sourced from different areas in Kaduna and neighbouring states and brought to Hanwa frog market which serves as collection, slaughter, processing and distribution point (Kia et al., 2017).

Sample collection

The frogs were collected from the Hanwa frog market from February to July, 2016. Twelve batches from which a total 202 were collected and labelled appropriately. They were grouped according to their source. The sources of the frogs brought from to Hanwa market included;

i. Zaria metropolis (Tudun Wada $n=20$, Sabon Gari $n=20$, University Farm $n=27$, Dabai $n=20$, Kafuru $\mathrm{n}=10$, Muchia $\mathrm{n}=10$ )

ii. Kaduna (Maraban Jos $n=10$ )

iii. Katsina $n=35$

iv. Zamfara $\mathrm{n}=15$

v. Kano $n=10$,)

All frogs obtained from these locations were brought to the Hanwa frog market in Zaria which serves as the collection, processing and distribution center for frogs. A total of 12 batches of frogs comprising of 202 frogs in total were used for this study.

\section{Media preparation}

Enrichment was done with Selenite broth (Oxoid Limited, England). All the media used for bacterial culture and identification were prepared in the laboratory according to the manufacturers' instructions and include; Deoxycholate agar; (Oxoid Limited, England), Nutrient agar slants (Oxoid Limited, England), Triple Sugar Iron agar (Antec Diagnostic Products TMUK), Urease Agar (Oxoid LTD, London), Simmon's citrate Agar (Himedia TM), Nutrient Agar (Oxoid LTD, London), Sulphur Indole motility (SIM) agar, Methyl Red/ Voges Proskauer agar and sugars (Arabinose, Maltose, Mannitol, Sorbitol, Dulcitol and Lactose) .

\section{Sample processing}

The frogs were placed inside a polythene bag and inserted into a refrigerator to achieve anaesthesia after which they were weighed, dissected and their sexes were determined as described elsewhere (Kia et al., 2017). Out of the 202 frogs that were sampled, 127 were males and 75 were females. The intestinal contents were scraped and inoculated each into $5 \mathrm{ml}$ of prepared Selenite $\mathrm{F}$ broth in $10 \mathrm{ml}$ capped tubes and incubated at $37^{\circ} \mathrm{C}$ for 24 hours.

\section{Bacterial isolation and identification}

A loopful of each broth inoculum with identifiable growth on Selenite broth was streaked on 
Deoxycholate Citrate Agar (DCA) and incubated for 24 hours at $37^{\circ} \mathrm{C}$. The colonial morphological growth of Salmonella and Shigella as observed on DCA was a smooth, raised, shiny or transparent colony with or without black centers was considered to be Salmonella and Shigella suspect, respectively (Cheesbrough, 1984; Hunt \& Goldsmid, 1990). The cultured organism was inoculated and stored on a Nutrient agar slant and refrigerated. Standard biochemical tests were used to identify Salmonella and Shigella among suspect isolates using conventional methods. Test conducted include; Triple sugar iron (TSI) prepared according to the manufacturer's recommendation. The isolate inoculated on TSI by stabbing. This was incubated for $37^{\circ} \mathrm{C}$ for 24 hours. Isolate were also streaked on prepared Urease agar slants, incubated at $37^{\circ} \mathrm{C}$ for 24 hours. Subsequently, Sulphur Indole motility (SIM) agar was inoculated for motility, $\mathrm{H}_{2} \mathrm{~S}$ and indole production. Presence of cloudiness around the stab-line after 24 hours at $37^{\circ} \mathrm{C}$ incubation indicated motile organism. Following addition of 2 drops of Kovac's reagent to the SIM tubes, a pinkishred colour layer indicates indole production. Blackening of the stab line shows $\mathrm{H}_{2} \mathrm{~S}$. Other biochemical tests, viz; MR, VP, Indole and Citrate were also conducted by inoculating putative isolates as described by Cheesbrough (1984) and Gaurav et al. (2013).

Further confirmation was carried out using sugar fermentation test following the recommendation of (Cheesbrough, 1984). A 10\% solution of Lactose, Dulcitol, Sorbitol, Maltose, Mannitol and Arabinose, each was prepared and autoclaved at $115^{\circ} \mathrm{C}$ for 20 minutes. Approximately $0.1 \mathrm{~g}$ of Bromothymol blue was added to $2.5 \mathrm{mls} 0.1$ molar $\mathrm{NaOH}$ and dissolved in $47.5 \mathrm{mls}$ of distilled water. The mixture was then added to a salinized buffered peptone water and autoclaved at $115 \circ \mathrm{C}$ for 20 minutes. To $9 \mathrm{mls}$ of this solution, $5 \mathrm{mls}$ of the sugar solution was added and thoroughly mixed. Into each test tube $5 \mathrm{mls}$ of the mixture was pipetted and suspected Salmonella or Shigella isolates as the case may be were inoculated into the solution and incubated at $37^{\circ} \mathrm{C}$ for 24 hours. Colour change of sugars indicated fermentation (Cheesbrough, 1984).

\section{Data analyses}

The data obtained were analyzed using statistical package for social science $16^{\text {th }}$ edition.

\section{Results}

The results were represented in tables and percentages. Chi-square was used to test for association between sex, location and Shigella or Salmonella spp isolated from the intestinal content of frogs sold for human consumption in Hanwa Zaria, Kaduna State. Values of $p<0.05$ were considered significant.

Salmonella and Shigella were found in 22 (10.9\%) and 27 (13.4\%) of the 202 frogs sampled. Of these 202 frogs sampled $127(62.9 \%)$ were males and 75 (37.1\%) were females (Tables 1 and 2).

The samples were evaluated for statistical relationship between the sex of the frogs and the Salmonella and Shigella occurrence rate (Tables 1 and 2). Among the frogs which had Salmonella $(n=22)$ and Shigella $(n=27)$, males were more infected with Salmonella (72.8\%) and Shigella $(66.7 \%)$ than the females $(27.2 \%$ and $33.3 \%$ respectively), thus giving a higher male to female ratio for both Salmonella and Shigella occurrence. This relationship was not statistically significant as the $p$ values were both $>0.05$ (Tables 1 and 2).

Table 1: Sex and weight distribution of edible frogs (Hoplobatrachus spp) infected with Salmonella from Hanwa frog market Zaria, Kaduna State, Nigeria

\begin{tabular}{|c|c|c|c|c|c|}
\hline Variable & $\begin{array}{l}\text { Total Number } \\
\text { Sampled (\%) }\end{array}$ & $\begin{array}{l}\text { No. positive (Source } \\
\text { Specific Rate (\%) }\end{array}$ & $\begin{array}{l}\text { Proportional } \\
\text { positivity Rate (\%) }\end{array}$ & $x^{2}$ & P-Value \\
\hline \multicolumn{6}{|l|}{ Sex } \\
\hline Male & 127(62.9) & $16(12.5)$ & 72.8 & 1.027 & 0.35 \\
\hline $\begin{array}{l}\text { Female } \\
\text { Weight } \\
\text { (grams) }\end{array}$ & 75 (37.1) & $6(8)$ & 27.2 & & \\
\hline 20- 72 & 40(19.8) & $4(10)$ & 18.2 & & \\
\hline $73-125$ & $130(64.4)$ & $14(10)$ & 63.6 & & \\
\hline $126-178$ & $23(11.4)$ & $4(17.4)$ & 18.2 & & \\
\hline $179-231$ & $6(3)$ & $0(0)$ & 0 & & \\
\hline $232-284$ & $3(1.5)$ & $0(0)$ & 0 & & \\
\hline Total & 202 & $22(10.9)$ & 100 & & \\
\hline
\end{tabular}


Table 2: Sex and weight distribution of edible frogs (Hoplobatrachus spp) infected with Shigella from Hanwa frog market Zaria, Kaduna State, Nigeria

\begin{tabular}{llcccc}
\hline Variable & $\begin{array}{c}\text { Total Number } \\
\text { Sampled (\%) }\end{array}$ & $\begin{array}{c}\text { No. positive (Source } \\
\text { Specific Rate (\%) }\end{array}$ & $\begin{array}{c}\text { Proportional } \\
\text { Positivity Rate (\%) }\end{array}$ & $x^{2}$ & P-Value \\
\hline Sex & & $18(14.2)$ & 66.7 & 0.1923 & 0.661 \\
Male & $127(62.9)$ & $9(12)$ & 33.3 & & \\
Female & $75(37.1)$ & & & \\
Weight & & & & \\
(grams) & & $1(2.5)$ & 3.7 & \\
$20-72$ & $40(19.8)$ & $16(12.3)$ & 59.3 & \\
$73-125$ & $130(64.4)$ & $5(21.7)$ & 18.5 & \\
$126-178$ & $23(11.4)$ & $4(66.7)$ & 14.8 & \\
$179-231$ & $6(3)$ & $1(33.3)$ & 3.7 & \\
$232-284$ & $3(1.5)$ & $27(13.4)$ & 100 & \\
\hline Total & 202 & &
\end{tabular}

Table 3: Locational distribution of edible frogs (Hoplobatrachus spp) infected with Salmonella from Hanwa frog market Zaria, Kaduna State, Nigeria

\begin{tabular}{clccc}
\hline S/N & Location/Code & $\begin{array}{c}\text { Total Number } \\
\text { Sampled }\end{array}$ & $\begin{array}{c}\text { No. positive (source } \\
\text { specific rate (\%) }\end{array}$ & $\begin{array}{c}\text { Proportional positivity } \\
\text { rate (\%) }\end{array}$ \\
\hline 1 & Tudun wada / TW & 20 & $4(20)$ & 18.2 \\
2 & Sabon gari/SG & 20 & $3(15)$ & 13.6 \\
3 & University farm/UF & 27 & $3(11.1)$ & 13.6 \\
4 & Katsina/KT & 35 & $3(8.5)$ & 13.6 \\
5 & Zamfara/ZF & 15 & $2(13.3)$ & 9.1 \\
6 & Maraban jos/MT & 10 & $3(20)$ & 13.6 \\
7 & Muchia/MCH & 10 & $3(30)$ & 13.6 \\
8 & Giwa/GW & 10 & $0(0)$ & 0 \\
9 & Wucheri/WCH & 15 & $2(13.3)$ & 0.1 \\
10 & Kano/KN & 10 & $0(0)$ & 0 \\
11 & Dabai/DAB & 20 & $0(0)$ & 0 \\
12 & Kafuru/KF & 10 & $0(0)$ & 100 \\
\hline
\end{tabular}

The samples were also evaluated for relationship in weight and the occurrence of Salmonella and Shigella. Findings revealed the highest occurrence (17.4\%) among the weight range $126 \mathrm{~g}-178 \mathrm{~g}$ for Salmonella and $66.7 \%$ for Shigella of weight range 179g-231g, while the weight specific rate showed that 63.6 and $59.3 \%$ of frogs all within the weight range of 73-125g were found with Salmonella and Shigella, respectively (Tables 1 and 2).

The occurrence of Salmonella and Shigella were also evaluated based on the source location (Tables 3 and 4) and it revealed the highest occurrence of Salmonella and Shigella in frogs sourced from Muchia (30\%) and Tundun Wada (40\%), respectively. Bio-typing for Salmonella and Shigella resulted in 22 and 30 suspected isolates respectively (Tables 5 and 6). Further analysis using Sugar fermentation tests for Salmonella and Shigella yielded 22 and 27 of the isolates gave the expected outcome (Tables 7 and 8). From the results (Tables 7 and 8), typical Shigella suspect gave alkaline and acid reaction on the slant and butt of the Triple Sugar Iron. There was no $\mathrm{H}_{2} \mathrm{~S}$ and indole production. Absence of cloudiness around the stab-line after 24 hours at $37^{\circ} \mathrm{C}$ incubation indicated no motile organisms.

\section{Discussion}

Salmonella and Shigella presence in $10.9 \%$ and $13.4 \%$, respectively, of frogs sampled in this study may be indicative of water contamination since frogs are not natural host nor reservoirs of Shigella spp (Pond, 2005). However, frogs serve as reservoir host of the Salmonella organism (CDC, 2008). 
Table 4: Locational distribution of Shigella isolated from edible frogs sold in Hanwa Zaria, Kaduna State Nigeria

\begin{tabular}{llll}
\hline S/N & Source/Codes & Total No. Sampled & No. Positive (\%) \\
\hline 1. & Tudunwada (TW) & 20 & $8(40.0)$ \\
2. & Sabongari(SG) & 20 & $5(25.0)$ \\
3. & Zamfara(ZF) & 15 & $1(6.7)$ \\
4. & Katstina(KT) & 35 & $3(8.6)$ \\
5. & Kano (KN) & 10 & $0(0.0)$ \\
6. & University farm (UF) & 27 & $2(7.4)$ \\
7. & Wucheri (WCH) & 15 & $2(13.3)$ \\
8. & Muchia (MCA) & 10 & $2(20.0)$ \\
9. & Dabai (DA) & 20 & $2(10.0)$ \\
10. & Giwa (GW) & 10 & $1(10.0)$ \\
11. & Kafuru (KF) & 10 & $1(10.0)$ \\
12. & Maraban Jos (MR) & 10 & $0(10.0)$ \\
\hline & Total & 202 & $27(13.4 \%)$ \\
\hline
\end{tabular}

Table 5: Biochemical Test for the suspected Salmonella isolate in Edible Frogs (Hoplobatrachus spp) from Hanwa Frog Market Zaria, Kaduna State, Nigeria

\begin{tabular}{|c|c|c|c|c|c|c|c|c|}
\hline $\begin{array}{l}\text { Location } \\
\text { code } \\
\text { (sample Id) }\end{array}$ & T.S.I & Urease & Citrate & Indole & MTY & MR & VP & Salmonella \\
\hline $\begin{array}{c}\text { U.F }(3,10 \\
12)\end{array}$ & $\begin{array}{l}\text { Alk/Acid_+ } \\
\mathrm{H}_{2} \mathrm{~S}\end{array}$ & $-V E$ & $+\mathrm{VE}$ & $-V E$ & $+\mathrm{VE}$ & $+\mathrm{VE}$ & -VE & $\checkmark$ \\
\hline $\mathrm{KT}(4,5,9)$ & $\begin{array}{l}\text { Alk/Acid_+ } \\
\mathrm{H}_{2} \mathrm{~S}\end{array}$ & -VE & $+\mathrm{VE}$ & -VE & $+\mathrm{VE}$ & $+\mathrm{VE}$ & -VE & $\checkmark$ \\
\hline$Z F(2,6)$ & $\begin{array}{l}\text { Alk/Acid_+ } \\
\mathrm{H}_{2} \mathrm{~S}\end{array}$ & -VE & $+V E$ & -VE & $+\mathrm{VE}$ & $+V E$ & -VE & $\checkmark$ \\
\hline $\operatorname{MR}(4,6)$ & $\begin{array}{l}\text { Alk/Acid_+ } \\
\mathrm{H}_{2} \mathrm{~S}\end{array}$ & -VE & $+\mathrm{VE}$ & -VE & $+\mathrm{VE}$ & $+\mathrm{VE}$ & -VE & $\checkmark$ \\
\hline $\begin{array}{c}\operatorname{MCA}(7,8, \\
10)\end{array}$ & $\begin{array}{l}\text { Alk/Acid_+ } \\
\mathrm{H}_{2} \mathrm{~S}\end{array}$ & $-V E$ & $+\mathrm{VE}$ & $-V E$ & $+\mathrm{VE}$ & $+\mathrm{VE}$ & -VE & $\checkmark$ \\
\hline $\mathrm{WCH}(7,12)$ & $\begin{array}{l}\text { Alk/Acid_+ } \\
\mathrm{H}_{2} \mathrm{~S}\end{array}$ & -VE & $+\mathrm{VE}$ & -VE & $+\mathrm{VE}$ & $+\mathrm{VE}$ & -VE & $\checkmark$ \\
\hline $\begin{array}{c}\text { TW }(6,7 \\
15,16)\end{array}$ & $\begin{array}{l}\text { Alk/Acid_+ } \\
\mathrm{H}_{2} \mathrm{~S}\end{array}$ & -VE & $+\mathrm{VE}$ & -VE & $+\mathrm{VE}$ & $+\mathrm{VE}$ & -VE & $\checkmark$ \\
\hline SG $(2,6,16)$ & $\begin{array}{l}\text { Alk/Acid_+ } \\
\mathrm{H}_{2} \mathrm{~S}\end{array}$ & -VE & $+\mathrm{VE}$ & -VE & $+\mathrm{VE}$ & $+\mathrm{VE}$ & -VE & $\checkmark$ \\
\hline
\end{tabular}

\section{KEYS}

UF= University Farm; KT= Katsina; ZF= Zamfara; MR= Maraban Jos; MCA= Muchia; WCH=Wucheri; TW=Tudun wada; SG=Sabon gari; Alk= Alkaline; T.S.I=Triple sugar iron; MTY=Motility; MR=Methyl Red; VP=Voges Proskauer

These frogs may serve as a means of transmission of zoonotic diseases both to man and animals especially to individuals processing them without good hand washing personal hygiene practice. Consumption of improperly cooked infected frogs may serve as a route of transmission of Salmonella and or Shigella (Mazzoni et al., 2003). This implies that the water bodies in which the frogs were sourced from may be contaminated by these infectious organisms or they might have acquired them from their feed. As such individuals involved in the catching or hunting and processing these frogs for meat purpose should ensure a high level of good hygienic practices as well in order to prevent and reduce the rate of infection. Varying percentages of Salmonella (for example, Tudun Wada (20\%), Sabon gari (15\%), Wucheri $(13.3 \%)$, Katsina with $8.5 \%)$ were found in the various areas sampled. Therefore this implies that the various locations may probably be contaminated with the salmonella microbes. The result of this study shows that the frogs processed for human consumption could be a source of bacterial infection to man and animals 
Table 6: Biochemical test result of the Shigella Isolate in edible Frogs from Hanwa Frog Market Zaria, Kaduna State, Nigeria

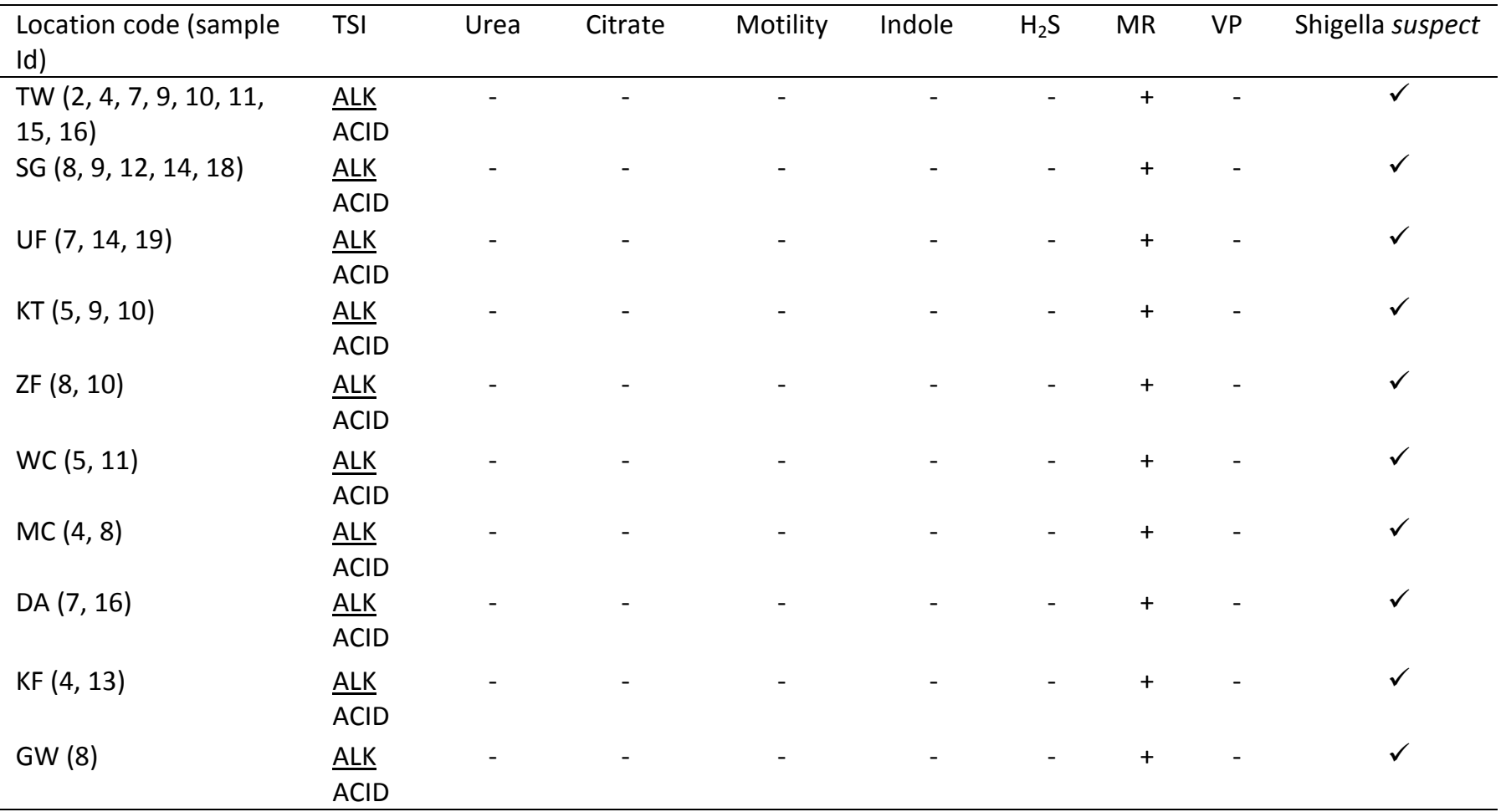

Keys: UF= University Farm; KT= Katsina; ZF= Zamfara; MR= Maraban Jos; MCA= Muchia; WCH=Wucheri; TW=Tudun wada; SG=Sabon gari; GW= Giwa; Alk= Alkaline; T.S.I=Triple sugar iron; MTY=Motility; MR=Methyl Red; VP=Voges Proskauer

Table 7: Sugar Fermentation Test for Suspected Salmonella Isolates in Frogs from Hanwa Frog Market in Zaria, Kaduna State, Nigeria

\begin{tabular}{|c|c|c|c|c|c|c|c|}
\hline $\begin{array}{l}\text { Location code } \\
\text { (sample Id) }\end{array}$ & Arabinose & Dulcitol & Maltose & Manitose & Lactose & Sucrose & $\begin{array}{l}\text { Sal. } \\
\text { Susp }\end{array}$ \\
\hline $\operatorname{U.F}(3,10,12)$ & + & - & + & + & - & - & $\sqrt{ }$ \\
\hline $\mathrm{KT}(4,5,9)$ & + & - & + & + & - & - & $\checkmark$ \\
\hline$Z F(2,6)$ & + & - & + & + & - & - & $\checkmark$ \\
\hline $\operatorname{MR}(4,6)$ & + & - & + & + & - & - & $\checkmark$ \\
\hline $\operatorname{MCA}(7,8,10)$ & + & - & + & + & - & - & $\checkmark$ \\
\hline $\mathrm{WCH}(7,12)$ & + & - & + & + & - & - & $\checkmark$ \\
\hline $\operatorname{TW}(6,7,15,16)$ & + & - & + & + & - & - & $\checkmark$ \\
\hline $\operatorname{SG}(2,6,16)$ & + & - & + & + & - & - & $\checkmark$ \\
\hline
\end{tabular}

KEYS UF= University Farm; KT= Katsina; ZF= Zamfara; MR= Maraban Jos; MCA= Muchia; WCH=Wucheri; TW=Tudun wada; SG=Sabon gari; Sal Susp= Salmonella suspect

and therefore good hygienic measures should be upheld during capture and processing.

There is also the need to educate the public on the cautious use of water from such rivers or dams, also that aquatic animal from such water bodies should be properly cooked before consumption. Similarly, the presence of Shigella (13.4\%) from frogs sampled in this study implies that the aquatic environment these frogs are harvested from may possess these infectious organisms. Irrigation farming among farmers in these 
Table 8: Sugar Fermentation test for suspected Shigella isolates in frogs from Hanwa Frog market in Zaria, Kaduna State, Nigeria

\begin{tabular}{|c|c|c|c|c|c|c|c|}
\hline Location Code (Sample Id) & Arabinose & Maltose & Manitole & Sorbitole & Dulcitole & Lactose & Inference \\
\hline $\operatorname{Tw}(2,4,7,9,10,11,15,16)$ & + & + & + & + & - & - & Shigella Spp \\
\hline $\operatorname{Sg}(8,9,12,14,18)$ & + & + & + & + & - & - & Shigella Spp \\
\hline Uf $(14,19)$ & + & + & + & + & - & - & Shigella Spp \\
\hline Kt $(5,9,10)$ & + & + & + & + & - & - & Shigella Spp \\
\hline $\mathrm{Zf}(10)$ & + & + & + & + & - & - & Shigella Spp \\
\hline Wc $(5,11)$ & + & + & + & + & - & - & Shigella Spp \\
\hline Da $(7,16)$ & + & + & + & + & - & - & Shigella Spp \\
\hline $\mathrm{Kf}(13)$ & + & + & + & + & - & - & Shigella Spp \\
\hline Gw (8) & + & + & + & + & - & - & Shigella Spp \\
\hline
\end{tabular}

KEYS: UF= University Farm; KT= Katsina; ZF= Zamfara; MR= Maraban Jos; MCA= Muchia; WCH=Wucheri; TW=Tudun wada; $\mathrm{SG}=$ Sabon gari

villages is done utilizing the water from these same water bodies, hence may serve as source of contamination of vegetables and other farm produce that are not cooked prior to eating. Shigella distribution on the bases of weight showed little or no presence of the microorganism at weight below $72 \mathrm{~g}$ and also weight above $232 \mathrm{~g}$ and higher specific rate of $4(66.6 \%)$ was obtained in frogs between 79-231g, this may relate to young and old frogs respectively which may be deterrent on the extent of movement hence not as exposed to contaminants as the others.

There was varying degree of Shigella isolation from edible frogs sold for human consumption in Hanwa Zaria, Kaduna state. This implies that infection of edible frogs by Shigella organism and contamination of the aquatic habitats varies from one place to another. This may be dependent on the presence or absence of faecal materials, environmental contamination and surface run-off (Esona et al., 2010).

There should be adequate and sustained public health enlightenment on dangers associated with unhygienic processing and consumption of improperly cooked frog meat. Further studies should be carried out using serotyping and molecular techniques to identify species of Salmonella and Shigella isolates obtained from culture and biotyping.

\section{References}

CDC (2008). Estimates of Food-borne illness in the United States, http://www.medicinenet.com/script/main/ art.asp?articlekey=101137, retrieved 04-102017.

Cheesbrough M (1984). Medical Laboratory Manual for Tropical Countries. Volume II. Microbiology. Heinman, Oxford London:
Tropical Health Technology, 1992 printing. Pp 400480.

Esona MD, Mijatovic-Rustempasic S, Conrardy C, Tong S, Kuzmin IV, Agwanda B, Robert F. B, Krisztian B, Michael N, Rupprecht CE, Gentsch JR \& Michael DB (2010). Reassortant group A rotavirus fr om strawcolored fruit bat (Eidolon helvum). Emerging Infectious disease, doi: 10.3201/eid 1612.101089.

Gaurav A, Singh SP, Gill JPS, Kumar R \& Kumar D (2013) Isolation and identification of Shigella spp. from human fecal samples collected from Pantnagar, India, Veterinary World, 6(7): 376-379.

Gupta A, Polyak CS, Bishop RD, Sobel J \& Mintz ED (2004). Laboratory-confirmed Shigellosis in the United States, 1989-2002: Epidemiologic Trends and Patterns. Clinical Infectious Diseases, 38(10): 1372-1377.

Hoelzer K, Merono S \& Weidmann M (2011). Animal contact as source of human non-typhoidal salmonellosis. Veterinary Research, 42:34.

Hunt ALC \& Goldsmid JM (1990). An investigation of culture media for the isolation of shigellae. Medical Laboratory Science, 47(3): 151-157.

Kia GSN, Ukuma BU, Odoba MB \& Okpanachi JU (2017). Occurrence of Cryptosporidium oocysts in edible frogs (Rana Species) sold for human consumption in hanwa frog market Zaria, Kaduna State, Nigeria. Journal of Coastal Life Medicine, 5(5): 202-205.

Leewenhoek AV, Sharma VK, Kaura YK \& Singh IP (1974) Frogs as carriers of salmonella and edwardsiella. Journal of Microbiogy, 40(1): 171-175. 
Marler C (2009). Outbreak of human salmonella typhymurium infections associated with contact with water frogs. Food Poison Journal. food. http. poisonjournal.com/foodborne-illnessoutbreak/outbreak-of-human-salmonellatyphimurium-infections-associated-withcontact-with-water-frog/, retrieved 04-102017.

Mazzoni R, Andrew A, Peter D, Perdomo E \& Gustavo $S$ (2003) Emerging pathogen in wild amphibians and frogs farmed for international trade. Emerging Infectious Disease, 9(8): 995.

Petmd (2008) Bacterial Infection In: Amphibians m.Petmd.Com/Reptile/Conditions/Skin/C_R p_Am_Mycobacteria, retrieved 01-102017.

Pond K (2005). Shigella, Water recreation and disease. Plausibility of associated infections: Acute effects, sequelae and mortality. WHO, Geneva. Pp 113-118.
Rebollar EA, Simonetti SJ, Shoemaker WR \& Harris RN (2016). Direct and indirect horizontal transmission of the antifungal probiotic bacterium janthinobacterium lividum on green frog (Lithobates clamitans) tadpoles. Applied Environmental Microbiology, 82(8): $2457-2466$.

Ryan KJ \& Ray CG (2004). Sherris Medical Microbiology, (fourth edition). McGraw Hill, USA. Pp 362-368.

Singh VK (2017). What is the zoological name of a frog. https://www.quora.com/What-is-thezoological-name-of-a-frog/, 23-01-2017.

Stuart SN, Chanson JS, Cox NA, Young BE, Rodrigues ASL, Fischman DL \& Waller RW (2004). Status and trends of amphibian declines and extinctions. Worldwide. Science, 306(5702): 1783 - 1786.

Yabuuchi, Eiko (2002). "Bacillus dysentericus (sic) 1897 was the first taxonomic rather than Bacillus dysenteriae 189. International Journal of Systematic and Evolutionary Microbiology, 52 (3): 1041. 